\title{
David Simonsen Digital
}

af Morten Thing, forskningsbibliotekar,

dr.phil., Roskilde Universitetsbibliotek.

"D. 30. september 2009 prosenterede Det Kongelige Bibliotek for en indbudt kereds forste del af et stort digitaliseringsprojekt $i$ Orientalsk og Judaistisk. Afdeling, der $i$ sin helhed skal omfatte alle haindskrifter fra David Simonsens bogsamling og hele brevarkivet på ansläet 50.000 breve.

Forelobig er storsteparten af bandskrifterne blevet tilgangeliggjort, omfattende 163 bind fra 20 lande på 15 forskellige sprog $i$ form af 26.000 billedfiler, d.v.s. nogenlunde det samme antal sider.

Overrabbiner, professor David Simonsens bibliotek og arkiv blev erbvervet i 1932 kort for hans dod af Det Kongelige Bibliotek med finansiel stotte fra Carlsbergfondet, Zeuthens Mindelegat og Det Mosaiske Trossamfund. Digitaliseringsprojektet er muliggjort ved en

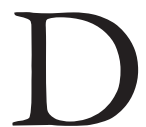
avid Simonsen var en heldig mand. Han arvede en formue, der gjorde, at han ikke behøvede at arbejde for at opretholde livet. Formuen var så stor, at han 49 år gammel, i 1902, tog sin afsked som overrabbiner ved Mosaisk Troessamfund i København for at hellige sig en bred vifte af interesser. Han var uddannet orientalist og rabbiner, og denne overordnede orientering styrede den myreflittige mand, for det donation fra agteparret Harry og Annette Rosenberg $i$ anledning of Harry Rosenbergs 70-års fodselsdag.

$V$ ed prosentationen talte direktor Erland Kolding Nielsen, fhv. overrabbiner Bent Melchior og forskningsbibliotekar, dr. phil. Morten Thing, Roskilde Universitetsbibliotek, bvis tale bringes her, og de nye webressourcer blev prasenteret af forskningsbibliotekar, fil.dr. Eva-Maria Jansson, der sammen med medarbejdere i Afdelingen for Digital Infrastruktur og Service har stäet for projektets udformning og gennemforelse."

Morten Thing har bl.a. skerevet De russiske jøder i København 1882-1943 (2008) og Min mors historie (2009), bvortil han har brugt David Simonsens arkiv og bibliotek."”

var ikke lediggang, han ønskede uafhæn-

Simonsen var en ortodoks rabbiner og en rationel filolog. Der var for ham ingen som helst modsætning mellem ortodoksien og videnskaben. Man skal imidlertid nok forstå sammenhængen derhen, at videnskaben var trådt i religionens tjeneste. Han var lærd, ikke kun som rabbiner med en encyklopædisk viden i Tora, Talmud og 


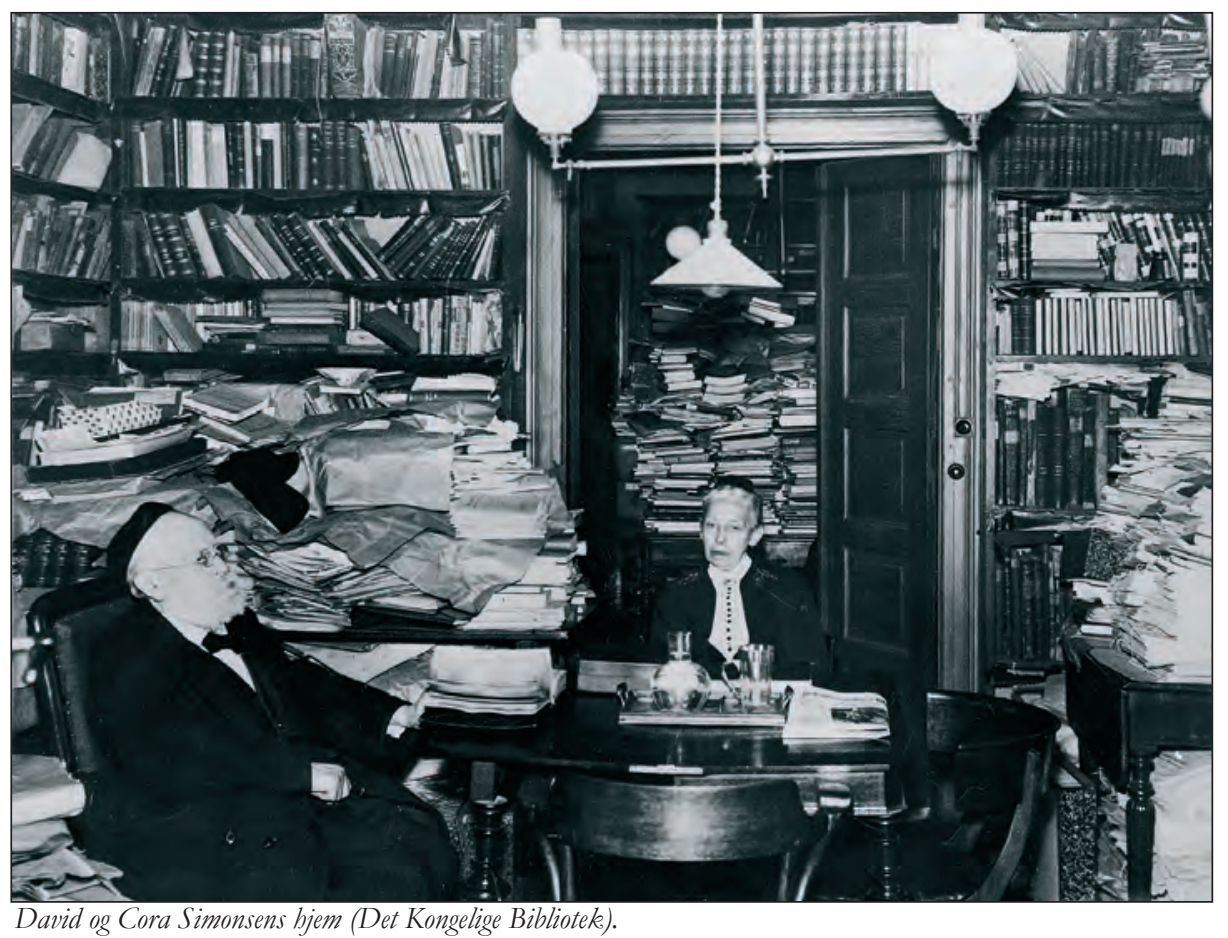

de mange jødiske teologiske forfattere og naturligvis i hebraisk og aramæisk som her er en forudsætning, men tillige i sprogvidenskab og historie, som på den ene eller anden måde knyttede sig til jødisk historie og religion.

Han brugte de sidste 30 år af sit liv til at opbygge et af landets største privatbiblioteker, som formentlig var på op mod 45.000 bind, og som var placeret i lejligheden i Skindergade. Der findes et foto af David Simonsen og hans kone Cora ved et bord i lejligheden. Han er fotograferet fra siden og tager sig stor ud. Men hun, som ses forfra, ser næsten ud til at blive væk mellem de mange bøger og stabler af papir alle vegne. I hans arkiv ligger flere nøgler til bogsamlingen med fx henvisning til 'reolen i gangen', så han selv kunne finde rundt i den. Men der ligger også i pakkevis af boghandlerregninger fra opbygningsperioden. For en boghistoriker med økonomiske forskningsinteresser ligger der guld og venter. Bogsamlingen omfatter både håndskrifter og bogtryk. Den omfatter religiøse bøger i massevis, men også enorme mængder af filologisk, historisk og politisk art. Bogsamlingen blev Det Kongelige Biblioteks i 1932, og når man som jeg har brugt mange, mange timer på Det Kongelige Biblioteks læsesal, så husker man, hvordan der med mellemrum dukkede bøger op, som tilhørte 'Bibliotheca Simonseniana', grundstammen i Judaistisk Afdeling. Simonsen brugte også af sin formue til velgørenhed, og han udfol- 
dede et omfattende støttearbejde. Man kan sige, at det faktisk var ad den vej, jeg selv først kom i kontakt med hans arkiv. Min mor bad mig nemlig engang i begyndelsen af 1980erne om at undersøge, hvad det var, der havde været mellem hendes far og Simonsen, et problem af en art, hun vidste ikke mere end det. På det tidspunkt lå Simonsens arkiv, som omfattede alt det papir, man kan se på fotografiet og meget mere, som ikke var bøger, i Judaistisk Afdeling og omfattede så vidt jeg husker flere hundrede arkivkapsler. Arkivet lå, som det var pakket ned i 1932, tilsyneladende uden systematik og uden en nøgle til dets opbygning. Så jeg mødte op flere dage om ugen i Judaistisk Afdeling og gennemgik kapsel efter kapsel for at finde noget om min morfar, en russisk jøde fra Polen. Jeg var faktisk ved at opgive ævred. Men pludselig faldt mine øjne på et foto af min morfar. Det lå sammen med en kort biografi, han havde skrevet på jiddish til David Simonsen. Den var jeg naturligvis glad for, men faktisk fandt jeg ikke det svar, min mor ledte efter, det dukkede først op, da brevene i arkivet var blevet ordnet. Kort fortalt, så havde Simonsen understøttet min morfar, så han kunne blive ingeniør i Tyskland. Aftalen indebar, at han skulle betale pengene tilbage, hvis han bestod sin eksamen. Det gjorde han imidlertid ikke, og Simonsen tabte sine penge - og min morfar var meget skamfuld. Han flygtede til Bruxelles og Paris, men kunne ikke finde arbejde. Han tog så til Danmark og blev meget syg. I et af de sidste breve skriver han at han tror han skal dø. På brevet har Simonsen noteret, at han sendte Mosaisk Troes-

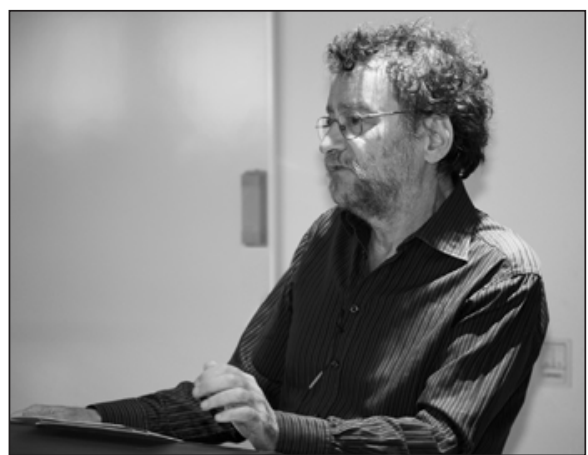

Morten Thing, f. 1945, bistoriker og forskningsbibliotekar på Roskilde Universitetsbibliotek; Thing beskaftiger sig med arbejderbistorie, jodisk bistorie, mellemostlig samtidshistorie og kulturbistorie. Foto: Det Kongelige Bibliotek.

samfunds fattiglæge ud til ham. Det reddede min morfar, men de omgikkes ikke derefter. Desværre var min mor død, da jeg kom så langt.

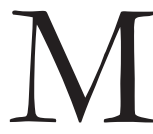

in systematiske gennembladning af dele af Simonsens arkiv var på mange måder en forbløffende rejse. Han var en mand, som var i brevforbindelse med alt, hvad der kunne krybe og gå i den jødiske og tilgrænsende verdener. Han var på samme tid en beskeden mand - og en mand som hjemmevant korresponderede med verdens kendteste lærde, videnskabsmænd og politikere. Han må have brugt adskillige timer hver dag på at skrive og læse breve. Og man kunne bare på kuverten skrive: Professor David Simonsen, Kobenhavn, Danmark, så kom brevet frem.

Simonsen brevvekslede fx med Georg Brandes, selvom han var upopulær blandt danske jøder, og han fortsatte efter Brandes havde meldt sig 


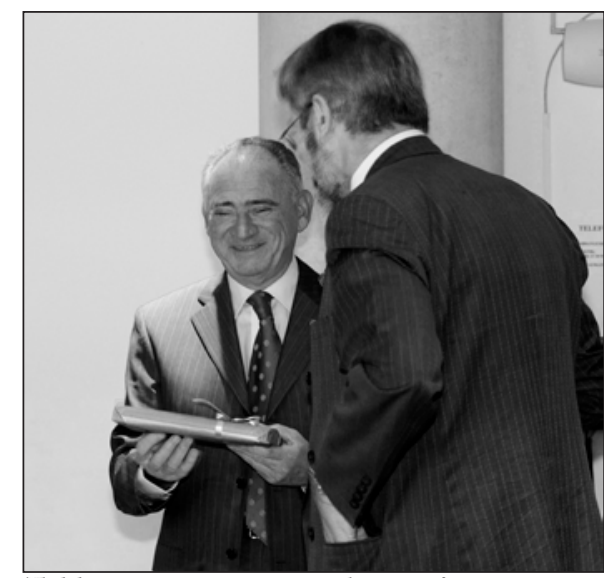

Takeket vare en meget generos donation fra agteparret Harry og Annette Rosenberg, kunne Det Kongelige

Bibliotek. offentliggore en samlet digitalisering af hovedparten af de baindskrifter, som i 1932 blev erbvervet som del af prof., rabbiner David Simonsens bogsamling, under navnet David Simonsens Håndskrifter. De digitaliserede baindskrifter rakker fra det eneste fragment fra Kairo-geniza'en i danske eje, et jodisk-arabisk brev fra det 12. (?) årbundrede, til moderne afskrifter af händskrifter $i$ engelske og franske biblioteker. Her ses Harry Rosenberg (t.v.) og Det Kongelige Biblioteks direktor Erland Kolding Nielsen ved offentliggorelsen af den digitaliserede samling. Foto: Det Kongelige Bibliotek.

ud af Troessamfundet. Brevvekslingen er kun en ud af mange, men den siger noget interessant om Simonsen. Han respekterede Georg Brandes, og det var i øvrigt gensidigt. Men han betragtede ham også som en styrke, han kunne bruge. Var der nye pogromer under udvikling, forsynede han Brandes med oplysninger $\mathrm{i}$ håbet $\mathrm{om}$, at han ville skrive om det offentligt. Og da Zionist Organisation oprettede et kontor i København under første verdenskrig, syntes Simonsen, at de måtte hilse på verdens kendteste jøde, Georg Brandes, og han anmodede Brandes om en audiens på Strandboulevarden for de zionistiske ledere.

Simonsen korresponderede med høj og lav i den jødiske verden. Han var således de indvandrede russiske jøder en god mand. Selvom han ikke kunne tale jiddish, kunne han godt læse det, og der er flere eksempler på det $\mathrm{i}$ arkivet. Han betragtede de nye indvandrere som en tiltrængt blodtransfusion til det stagnerende københavnske jødiske samfund. Han forblev også en central mand i Mosaisk Troessamfund, om end uden nogen formel status. Han var i forbindelse med repræsentantskabet og formidlede i en vis udstrækning mellem de gamle dansk-jødiske familjer og de nye indvandrere. Og ledelsen af trossamfundet spurgte ham til råds i prekære situationer, $\mathrm{fx}$ under rabbinerstriden 1910-12, hvor repræsentantskabet havde fyret overrabbiner Tobias Lewenstein. Også økonomisk støttede han. Han skød således penge i projektet for at få opført et jødisk Folkets Hus i København, hvor alle de jødiske foreninger kunne mødes. Det blev desværre ikke til noget.

Simonsen var med til at lave opslag til Ordbog over det danske Sprog. Hvis et ord tangerede hans encyklopædiske viden, blev han spurgt til råds. Han kommunikerede med rabbinere og jødiske lærde i Østeuropa, Vesteuropa, USA og ikke mindst i Palæstina. Men det var ikke kun teologiske emner, som optog ham. Han var levende optaget af den politik, som foregik i den sekulære verden. Han var modstander af zionismen, men nærmede sig den mere og mere gennem livet. Han var politisk 
konservativ og ofrede en del krudt på at overbevise Statspolitiet om, at der ikke var nogen som helst forbindelse mellem jødedom og kommunisme. Det var nemlig en forestilling, som Statspolitiet havde formentlig fra eksilrussiske og tyske kilder, at jøderne var ude på at erobre verdensherredømmet og til det formål havde udviklet kommunismen.

Han var modstander af, at de indvandrede russiske jøder brugte jiddish og mente, at her i Danmark skulle de tale dansk. Det var ikke så meget fordi han, som andre jødiske teologer uddannet $\mathrm{i}$ Tyskland, så jiddish som blot 'forkert tysk'. For ham var jiddish ikke et jødisk sprog i egentlig forstand, dét var kun hebraisk og aramæisk. Og dansk kunne man lære i de to jødiske skoler Mosaisk Drengeskole og Carolineskolen, og det hellige sprog kunne man lære i Religionsskolen, som han støttede entusiastisk.

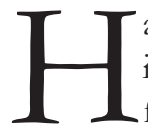

ans arkiv er en guldgrube, som ikke blot bør være interessant for os, der forsker i jødisk

historie i Danmark. Mange internationale forskere vil kunne hente meget ud af arkivet. Udover alle de håndskrevne breve er der i arkivet en masse tryksager, som han har fået tilsendt og gemt, tryksager som det ellers kan være svære at finde. Judaister, teologer, filologer, historikere, kulturhistorikere vil finde rigtig meget råstof til deres forskning. Både hans arkiv og hans bibliotek har efter nazismens hærgen i jødiske arkiver og synagoger fået en endnu større betydning. Tryk og håndskrifter, som er blevet brændt i Tyskland og Polen, er bevaret $\mathrm{i}$ København.

akket være Harry og Annette
Rosenbergs initiativ bliver vig-
tige dele af denne samling nu tilgængelig som scanninger, som kan søges direkte i Det Kongelige Biblioteks database Rex. Omkring 170 håndskrevne bøger, såkaldte codices, på hebraisk, aramæisk, jiddish, judeo-arabisk og flere andre sprog bliver tilgængelige, og det samme bliver de omkring 50.000 breve efterhånden. Og i et meget læservenligt software, hvor man læser de hebraiske og jiddishe skrifter fra den rigtige ende. For forskere vil det betyde, at de ikke behøver at tage til København for at konsultere originalerne. De kan læse dem i digital form på Det Kongelige Biblioteks website. Det er et enormt spring for jødisk orienteret forskning og en hjælp, der vil blive modtaget med taknemmelighed af dette lille segment af forskersamfundet verden over. Men altså også mange forskere uden for vores lille klub.

David Simonsens digitale håndskrifter findes på: http://www.kb.dk/manus / judsam/2009/sep/dsh/da

Mere om digitaliseringen og samlingen: http://www.kb.dk/da/nb/samling/js/ dsh/

Listen over brevskrivere i Simonsens arkiv: http://www.kb.dk/export/sites/ $\mathrm{kb} \_\mathrm{dk} / \mathrm{da} / \mathrm{nb} / \mathrm{samling} / \mathrm{js} /$ jsdownloads/ registrant2006.pdf 


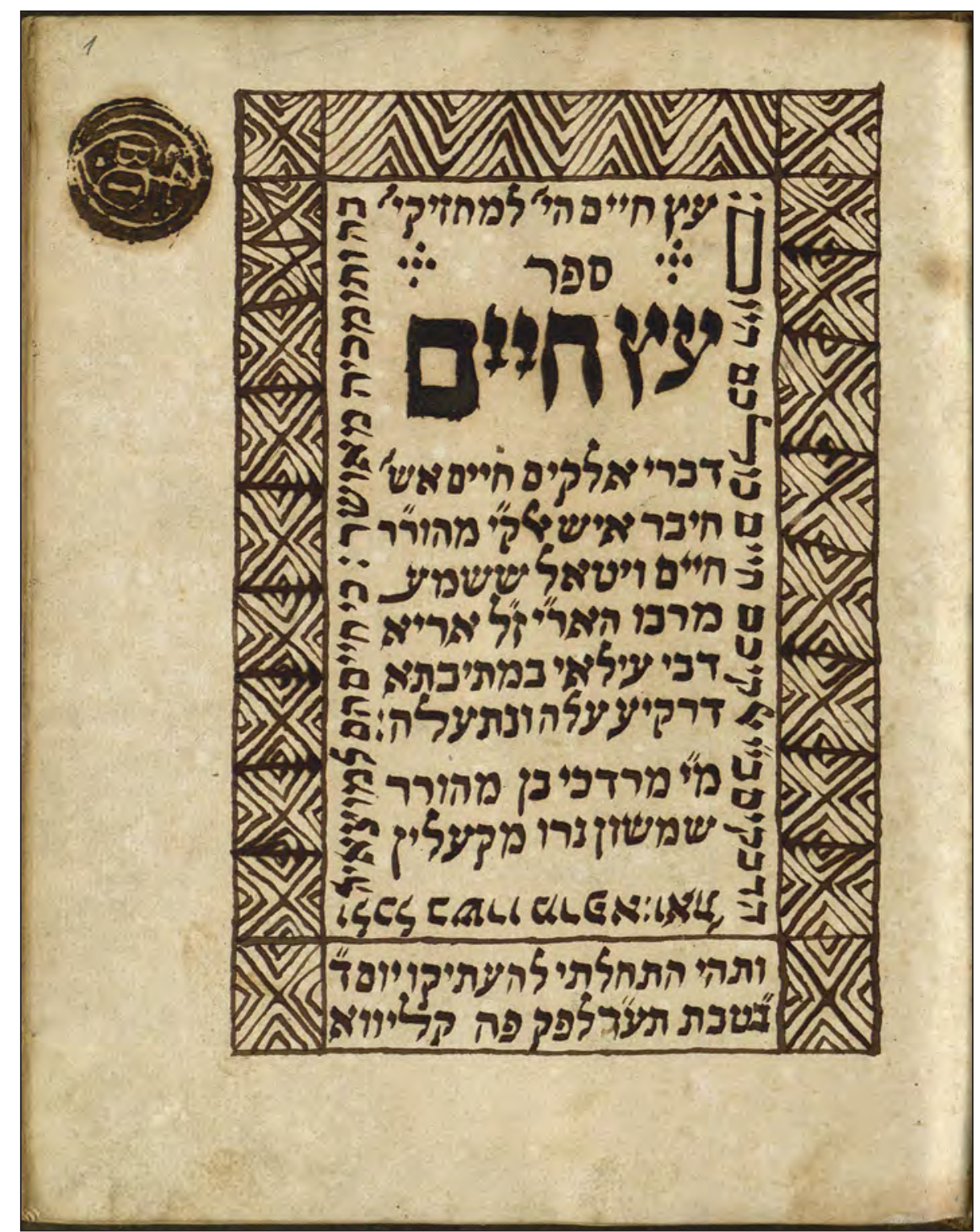

Ets hayim. Hebraisk kabbalistisk håndskrift fra begyndelsen af 1700-tallet fra Tyskland, David Simonsens samling (Det Kongelige Bibliotek). 